
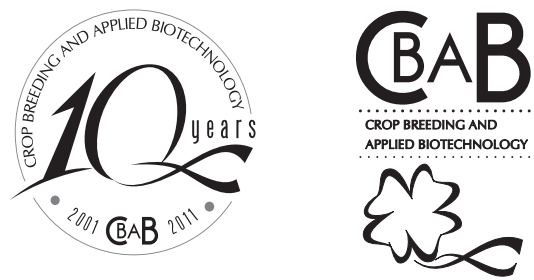

\title{
Characterization of tomato accessions for resistance to early blight
}

José Fernando Jurca Grigolli ${ }^{1 *}$, Mirian Maristela Kubota ${ }^{1}$, Daniel Pedrosa Alves ${ }^{1}$, Gabriel Belfort Rodrigues ${ }^{1}$, Carine Rezende Cardoso $^{2}$, Derly José Henriques da Silva ${ }^{1}$ and Eduardo Seiti Gomide Mizubuti ${ }^{2}$

Received 14 May 2010

Accepted 16 November 2010

\begin{abstract}
The purpose of this study was to characterize 50 tomato genotypes of the Vegetable Genebank of the Federal University of Viçosa. They were evaluated together with the controls Débora, Fanny and Santa Clara, in a randomized block design with two replications. The experiment was conducted in a research field of the UFV, from February to May 2007. We evaluated the disease severity, which is the percentage of diseased leaf area. The severity values were transformed into area under the disease progress curve (AUDPC), improving the result visualization. The analysis of variance and grouping of AUDPC means by the ScottKnott test at $5 \%$ significance were performed. The accessions BGH-2081, BGH-2034, BGH-700, BGH-2057, BGH-2035, BGH2054, $B G H-2018, B G H-2065, B G H-2008$, and BGH-2032 had a lower mean AUDPC than the controls and are therefore indicated for future breeding programs.
\end{abstract}

Key words: Alternaria solani; Solanum lycopersicon; genebank; biotic stress; genetic resources; pre-breeding.

\section{INTRODUCTION}

The plant diversity in the Solanaceae family is great and several species of economic importance, e.g., tomato (Tambarussi et al. 2009) belong to it. Tomato is related to an intensive use of pesticides since numerous factors can cause significant crop losses, e.g., pests and diseases (Schuelter et al. 2006). It is estimated that fungal diseases of tomato are responsible for a $30 \%$ increase in production costs in fungicides used to combat these diseases (Lopes and Santos 1994). Among the diseases, early blight, caused by the fungus Alternaria solani, is one of the most important and frequent diseases of the crop nation- and worldwide (Jones et al. 1991, Balbi-Peña et al. 2006). In plantations in the U.S., Australia, Israel, UK and India, these losses range from 35 to $78 \%$ (Basu 1974, Datar and
Mayee 1982). In Brazil, a disease survey in tomato areas in Minas Gerais stated that the incidence of early blight was one of the highest $(88 \%)$ and that 18 fungicide applications had to be sprayed during the crop cycle to control this disease (Vale et al. 1992).

The destructive power of the disease is considerable; it attacks leaves, stems and fruits, eventually defoliating the plants and reducing yield and fruit quality (Castro et al. 2000, Foolad et al. 2002, Chaerani et al. 2007). Increased susceptibility to early blight is usually associated with mature tissue, and is more common during the fruiting phase. Severe epidemics of the disease occur at physiological plant maturity, since older and senescing leaves are more susceptible (Barratt and Richards 1944, Barksdale 1971, Martin and Hepperly 1987, Nash and Gardner 1988, Maiero et al. 1990).

\footnotetext{
${ }^{1}$ Universidade Federal de Viçosa (UFV), Departamento de Fitotecnia, Av. P. H. Rolfs, s/n, Campus Universitário, 36.571-000, Viçosa, MG, Brazil. *E-mail: jose_fernando_jg@yahoo.com.br

${ }^{2}$ UFV, Departamento de Fitopatologia
} 
Although genetic resistance is the most efficient control method, there is still no tomato variety available with acceptable levels of resistance to early blight. As a result, the main control method involves the application of protective and systemic fungicides, raising production costs, besides being little effective in wetter periods (Holm et al. 2003). Furthermore, fungicides are often used at excessive doses, causing environmental contamination risks and health problems of workers and consumers (Batista et al. 2006). Generally, these fungicides are applied every 7-10 days, without taking the disease development or epidemiological conditions into consideration (Patterson and Nokes 2000).

Improvement programs from a base population with high genetic variability will increase the chances of establishing superior genotypes successfully in subsequent generations of selection (Hallauer and Miranda Filho 1988). These parents may be selected from old cultivars of the cultivated species as well as from wild species of the same genus represented in genebanks (Vallois et al. 1996). One of the main factors contributing to the low use of parents in breeding programs is that breeders are not aware of the genetic resources available in genebanks (Morales et al. 1997).

Thus, genebanks are important tools in plant breeding programs and should be used, as in this case, as gene sources to confer disease resistance to commercial tomato cultivars. With this purpose, the Federal University of Viçosa, supported by the Rockefeller Foundation, officially created the Vegetable Genebank of the Federal University of Viçosa (BGH - UFV) in 1966, the oldest in Latin America (Silva et al. 2001).

Thus, this study aimed to characterize 50 tomato accessions of the UFV genebank for resistance to early blight in order to detect useful genes for tomato breeding programs.

\section{MATERIAL AND METHODS}

The experiment was conducted from February to May 2007 in a research garden of the Plant Science Department, of the university Federal of Viçosa (UFV), in Viçosa, state of Minas Gerais (lat $20^{\circ} 45^{\prime}$ S, long 40 $38^{\prime} \mathrm{W}$, and alt $690 \mathrm{~m}$ asl).

The following 50 tomato accession from the UFV Vegetable genebank were used: BGH-700, BGH-2000, BGH2002, BGH-2003, BGH-2004, BGH-2006, BGH-2008, BGH2013, BGH-2014, BGH-2016, BGH-2017, BGH-2018, BGH-
2019, BGH-2020, BGH-2021, BGH-2026, BGH-2027, BGH2029, BGH-2032, BGH-2033, BGH-2034, BGH-2035, BGH2038, BGH-2039 Amarelo, BGH-2039 Vermelho, BGH-2041, BGH-2046, BGH-2052, BGH-2054, BGH-2055, BGH-2057, BGH-2060, BGH-2062, BGH-2064, BGH-2065, BGH-2068, BGH-2069, BGH-2071, BGH-2072, BGH-2073, BGH-2074, BGH-2075, BGH-2076, BGH-2077, BGH-2078, BGH-2080, BGH-2081, BGH-2082, BGH-2083, and BGH-2086. Besides, the cultivars Débora and Fanny were used as controls and Santa Clara as susceptibility standard (Tófoli and Kurozawa 1993). All accessions, provided by Purdue University (USA), were of the Solanum lycopersicon species and included in the UFV genebank in November 1966 (data of color, fruit size and shape, plant production and soluble solids content of each accession in Table 1).

The experiment was established in a randomized block design with two replications and five plants per plot, with three plants. The seedlings were grown in polystyrene trays of 128 cells containing a commercial substrate. When the plants had four leaves, 25 days after sowing, they were transplanted to an area previously used for tomato cultivation. The soil was plowed, disked and limed according to recommendations of Ribeiro et al. (1999).

Plants were spaced $0.60 \mathrm{~m}$ and rows $1.00 \mathrm{~m}$ apart. Technical-cultural practices were applied weekly, as well as topdressings. The crop was sprinkler-irrigated, to increase the local moisture and boost the epidemiological disease process.

To obtain the inoculation solution, diseased leaves were collected in different planting areas and A.solani propagules isolated in the plant pathology laboratory of UFV. After isolation and identification, the pathogen was cultured as described by Foolad et al. (2000) and the pathogenicity of detached leaflets of 45-day-old tomato plants evaluated. The five isolates used in this study were selected according to the pathogen aggressiveness (Table 2).

These five isolates were cultured separately on PDA medium $\left(25 \pm 2{ }^{\circ} \mathrm{C}, 12\right.$-h photoperiod $)$. On the seventh day of incubation, $15 \mathrm{~mL}$ of distilled water was added to each dish and the fungus was bruised and mycelium removed with a brush. Sporulation on the dishes without lids was stimulated $\left(25 \pm 2{ }^{\circ} \mathrm{C}, 12\right.$-h black light photoperiod) for $60 \mathrm{~h}$ after mycelium removal. Thereafter, the conidia were removed with $10 \mathrm{~mL}$ of distilled water added to each dish, by scraping the surface with a soft toothbrush. Then the suspension was filtered through a double layer of sterile gauze. 
JFJ Grigolli et al.

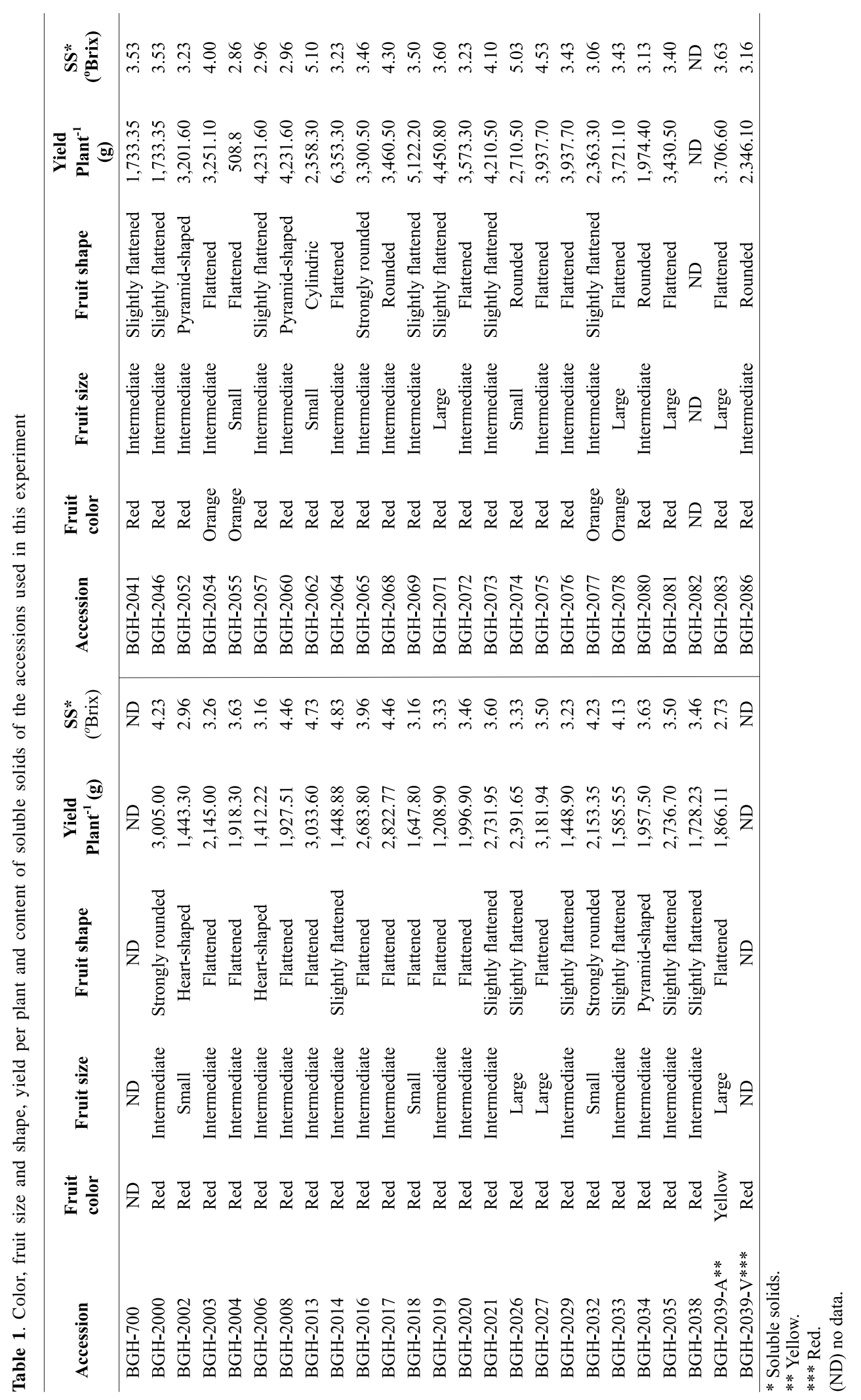


Table 2. Origin and sampling date of A.solani isolates used in this experiment

\begin{tabular}{cccc}
\hline Isolate & Host & Origin & $\begin{array}{c}\text { Sampling } \\
\text { date }\end{array}$ \\
\hline AS 086 & Tomato & Ponta Grossa-PR & $04 / 2000$ \\
AS 207 & Tomato & Bueno Brandão-MG & $01 / 2006$ \\
AS 242 & Tomato & Conselheiro Lafaiete-MG & $05 / 2005$ \\
AS 272 & Tomato & Domingos Martins-ES & $01 / 2005$ \\
AS 339 & Tomato & Colméia-TO & $11 / 2005$ \\
\hline
\end{tabular}

Table 3. Means of the area under the disease progression curve (AUDPC) for 50 tomato accessions of the UFV genebank, evaluated for resistance to Alternaria solani

\begin{tabular}{llll}
\hline Accession & AUDPC & Accession & AUDPC \\
\hline BGH-2002 & 44.47 A & BGH-2071 & $23.01 \mathrm{D}$ \\
BGH-2055 & $42.16 \mathrm{~A}$ & Santa Clara & $22.53 \mathrm{D}$ \\
BGH-2004 & $39.82 \mathrm{~A}$ & BGH-2060 & $22.23 \mathrm{D}$ \\
BGH-2003 & $37.26 \mathrm{~B}$ & BGH-2029 & $21.10 \mathrm{D}$ \\
BGH-2046 & $37.01 \mathrm{~B}$ & BGH-2000 & $20.97 \mathrm{D}$ \\
BGH-2052 & $34.19 \mathrm{~B}$ & BGH-2076 & $20.70 \mathrm{D}$ \\
BGH-2038 & $33.99 \mathrm{~B}$ & BGH-2069 & $19.56 \mathrm{D}$ \\
BGH-2068 & $32.54 \mathrm{~B}$ & BGH-2021 & $19.24 \mathrm{D}$ \\
BGH-2041 & $30.56 \mathrm{C}$ & BGH-2006 & $18.90 \mathrm{D}$ \\
BGH-2082 & $29.90 \mathrm{C}$ & BGH-2083 & $18.71 \mathrm{D}$ \\
BGH-2072 & $28.83 \mathrm{C}$ & BGH-2026 & $18.56 \mathrm{D}$ \\
BGH-2080 & $28.47 \mathrm{C}$ & BGH-2020 & $18.33 \mathrm{D}$ \\
BGH-2027 & $28.23 \mathrm{C}$ & BGH-2016 & $18.05 \mathrm{D}$ \\
BGH-2039-Red & $27.33 \mathrm{C}$ & BGH-2062 & $17.66 \mathrm{D}$ \\
BGH-2064 & $27.28 \mathrm{C}$ & BGH-2033 & $17.38 \mathrm{D}$ \\
BGH-2086 & $26.84 \mathrm{C}$ & BGH-2014 & $16.61 \mathrm{D}$ \\
BGH-2077 & $26.80 \mathrm{C}$ & BGH-2081 & $15.29 \mathrm{E}$ \\
BGH-2039-Yellow & $26.76 \mathrm{C}$ & BGH-2034 & $15.19 \mathrm{E}$ \\
Fanny & $26.03 \mathrm{C}$ & BGH-700 & $14.86 \mathrm{E}$ \\
Debora & $25.83 \mathrm{C}$ & BGH-2057 & $14.26 \mathrm{E}$ \\
BGH-2013 & $25.66 \mathrm{C}$ & BGH-2035 & $13.53 \mathrm{E}$ \\
BGH-2019 & $25.59 \mathrm{C}$ & BGH-2054 & $12.07 \mathrm{E}$ \\
BGH-2075 & $24.47 \mathrm{C}$ & BGH-2018 & $11.50 \mathrm{E}$ \\
BGH-2073 & $24.06 \mathrm{C}$ & BGH-2065 & $11.21 \mathrm{E}$ \\
BGH-2017 & $24.00 \mathrm{C}$ & BGH-2008 & $9.48 \mathrm{E}$ \\
BGH-2078 & $23.82 \mathrm{C}$ & BGH-2032 & $8.57 \mathrm{E}$ \\
BGH-2074 & $23.74 \mathrm{C}$ & & \\
\hline
\end{tabular}

Means followed by the same letter in the column did not differ from each other at $5 \%$ probability, by the Scott-Knott test.

Coefficient of variation $=14.04 \%$; Mean standard error $=2.350 ;$ Standard deviation $=3.324$.

All plants were inoculated 45 days after transplanting with a manual backpack sprayer $(5 \mathrm{~L})$. A suspension of $10^{4}$ conidia $\mathrm{mL}^{-1}$ was applied, consisting of a mixture of the above isolates. No fungicide was used after inoculation. There were five assessments, the first 48 hours after inoculation and the others every three days.
The disease severity was assessed on all leaves. The diseased leaf area was considered in percent according to Horsfall and Barrat (1945) (0 means $0 \%$ of diseased leaf area and 100 simply means $100 \%$ leaf area damaged by the pathogen). This criterion is based on the size and number of lesions; the two components are independent of each other in the disease progress (Boff et al. 1991). Therefore, the percentage of defoliation and number of infected leaves can be analyzed as a direct result of the higher or lower susceptibility of a plant.

The assessments were carried out by three raters, trained according to the program Severity Pro 1.0 (Nutter and Litwiller 1998), and three previously labeled plants of each plot were evaluated. All leaves of each plant were evaluated and the grades of each leaf of the same plant given by the three evaluators averaged. The disease severity on each plant was determined according to the average of all leaves of a plant. These severity values were used to calculate the area under the disease progress curve (AUDPC), based on the model proposed by Campbell and Madden (1990).

$$
A A C P D=\sum_{1}^{n-1} \frac{(Y i+Y i+1)}{2}(t i+1-t i)
$$

where $n$ is the number of reviews, $y$ percentage of disease severity and $t$ is the time spent with the evaluations, in days.

Analysis of variance was performed with the AUDPC data and means of genotypes were grouped by the ScottKnott test at $5 \%$ probability, using software Genes (Cruz 1997).

\section{RESULTS AND DISCUSSION}

The data of the disease reaction represented by the AUDPC showed that the difference between the tomato accessions from the UFV genebank (Table 3) was significant, demonstrating genetic variability among genotypes. The AUDPC values of the sub-samples BGH2081, BGH-2034, BGH-700, BGH-2057, BGH-2035, BGH-2054, BGH-2018, BGH-2065, BGH-2008, and BGH-2032 were lower than the susceptibility standard Santa Clara.

According to Paula and Oliveira (2003), the AUDPC represents epidemics best. According to these authors, this curve can also be helpful in the evaluation of control strategies and prediction of future disease levels.

The use of severity to evaluate the intensity of leaf spot - diseases is probably more appropriate (Kranz 1988). Moreover, according to this author, the severity criterion 
JFJ Grigolli et al.

can be used as a differentiating characteristic of resistance or susceptibility of accessions.

In the experimental period, temperatures were high in the early crop development, and milder in the later stages (Table 4). After inoculation, temperatures were mostly around $20^{\circ} \mathrm{C}$ on average, the leaves were exposed to wetness for nine hours per week. In a similar study, Paula and Oliveira (2003) observed an AUDPC of 484.33 for Santa Clara, while in this study the AUDPC of the same cultivar was 22.43. This difference may be due to environmental conditions, which were not ideal for the pathogen development in the test period.
Maiero et al. 1989). Therefore, evaluations of plant resistance in the field, as in the present study, are more appropriate since the reliability of the results is greater (Foolad et al. 2000).

The AUDPC values for early blight on the accessions were lower than of the susceptibility standard Santa Clara. The resistance level of cultivars on the market is insufficient to be recommended as a control method of early blight (Foolad et al. 2000, Martin and Hepperly 1987). Some studies show that tomato sub-samples with higher resistance levels than of those on the market are being used in breeding programs, leading to the development of cultivars

Table 4. Mean monthly rainfall and maximum, minimum and mean temperatures in Viçosa-MG in the test period

\begin{tabular}{lcccc}
\hline Month & Rain $(\mathrm{mm})$ & Maximum Temperature $\left({ }^{\circ} \mathbf{C}\right)$ & Minimum Temperature $\left({ }^{\circ} \mathbf{C}\right)$ & Mean Temperature $\left({ }^{\circ} \mathbf{C}\right)$ \\
\hline February & 149 & 30.36 & 18.73 & 22.30 \\
March & 122 & 29.99 & 17.99 & 22.00 \\
April & 53 & 27.66 & 17.26 & 20.00 \\
May & 27 & 26.75 & 13.30 & 17.60 \\
\hline
\end{tabular}

Reports in the literature about the climate effect on the development of tomato early blight suggest that severe epidemics occur most frequently at temperatures $>25^{\circ} \mathrm{C}$, coupled with high humidity (Maffia et al. 1980, Rotem 1994). In addition, moisture favors $A$. solani sporulation, further increasing the disease severity in the test (Sherf and Macnab 1986).

The assessments after inoculation showed that the disease symptoms were expressed in the plant, aggravating gradually in some accessions. The resistance of most genotypes characterized under laboratory conditions was not confirmed under field conditions (Foolad et al. 2000, with high pathogen resistance levels (Barksdale and Stoner 1973, Gardner 1988, Nash and Gardner 1988, Gardner and Shoemaker 1999). Thus, the sub-samples BGH-700, BGH-2008, BGH-2018, BGH-2032, BGH-2034, BGH-2035, BGH-2054, BGH-2057, BGH-2065, and BGH-2081 can be used as resistance sources in breeding programs.

\section{ACKNOWLEDGEMENTS}

The authors are indebted to the Research Foundation of the State of Minas Gerais - FAPEMIG for the undergraduate students' research scholarship and to the UFV for providing the necessary infrastructure. 


\title{
Caracterização de subamostras de tomateiro quanto à resistência à pinta preta
}

\begin{abstract}
RESUMO - O objetivo deste trabalho foi caracterizar 50 subamostras de tomateiro do Banco de Germoplasma de Hortaliças da Universidade Federal de Viçosa (BGH-UFV). Foram avaliadas juntamente com as testemunhas Débora, Fanny e Santa Clara, em experimento em blocos ao acaso, com duas repetições. O experimento ocorreu na Horta de Pesquisas da UFV, no período de fevereiro a maio de 2007. Avaliou-se a severidade da doença, que é a porcentagem da área foliar lesionada. Os valores de severidade foram transformados em área abaixo da curva de progresso da doença (AACPD), possibilitando uma melhor visualização dos resultados. Foi realizada a análise de variância, seguido do agrupamento das médias de AACPD pelo teste de Scott-Knott, a $5 \%$ de significância. As subamostras BGH-2081, BGH-2034, BGH-700, BGH-2057, BGH-2035, BGH-2054, BGH-2018, BGH-2065, BGH-2008 e BGH-2032 apresentaram menor média de AACPD em relação às testemunhas, podendo ser utilizadas em futuros programas de melhoramento.
\end{abstract}

Palavras-chave: Alternaria solani; Solanum lycopersicon; banco de germoplasma; estresse biótico; recursos genéticos; prémelhoramento.

\section{REFERENCES}

Balbi-Peña MI, Becker A, Stangarlin JR, Franzener G, Lopes MC and Schwan-Estrada KRF (2006) Controle de Alternaria solani em tomateiro por extratos de Curcuma longa e curcumina - II avaliação in vivo. Fitopatologia Brasileira 31: 401-404.

Barksdale TH (1971) Field evaluation for tomato early blight resistance. Plant Disease Report 55: 807-809.

Barksdale TH and Stoner AK (1973) Segregation for horizontal resistance to tomato early blight. Plant Disease Report 57: 964-964

Barratt RW and Richards MC (1944) Physiological maturity in relation to Alternaria blight in tomato. Phytopathology 34: 997.

Basu PK (1974) Measuring early blight, its progress and influence on fruit losses in nine tomato cultivars. Canadian Plant Disease Survey 54: 45-51.

Batista DC, Lima MA, Haddad F, Maffia LA and Mizubuti ESG (2006) Validation of decision support systems for tomato early blight and potato late blight, under Brazilian conditions. Crop Protection 25: 664-670.

Boff P, Zambolim L and Vale FXR (1991) Escalas para avaliação de severidade da mancha-de-estenfílio (Stemphylium solani) e da pinta preta (Alternaria solani) em tomateiro. Fitopatologia Brasileira 16: 280-283.

Campbell CL and Madden LV (1990) Introduction to plant disease epidemiology. John Wiley \& Sons, New York, 532p.

Castro MEA, Zambolim L, Chaves GM, Cruz CD and Matsuoka K (2000) Variabilidade patogênica de Alternaria solani, agente causal da pinta-preta do tomateiro. Summa Phytopatologica 8: $24-28$.

Chaerani R, Groenwold R, Stam P and Voorrips RE (2007) Assessment of early blight (Alternaria solani) resistance in tomato using a drop inoculation method. Journal of General Plant Pathology 73: 96-103.
Cruz CD (1997) Programa Genes - aplicativo computacional em genética e estatística. Editora UFV, Viçosa, 442p.

Datar VV and Mayee CD (1982) Conidial dispersal of Alternaria solani in tomato. Indian Phytopathology 35: 68-70.

Foolad MR, Ntahimpera N, Christ BJ and Lin JY (2000) Comparison of field, green-house, and detached-leaflet evaluations of tomato germ plasm for early blight resistance. Plant Disease 84: 967-972.

Foolad MR, Zhang M, Khan AA, Niño-Liu D and Lin G (2002) Identification of QTLs for early blight (Alternaria solani) resistance in tomato using backcross populations of a Lycopersicon esculentum x L. hirsutum cross. Theoretical and Applied Genetics 104: 945-958.

Gardner RG (1988) NC EBR-1 and NC EBR-2 early blight resistant tomato breeding lines. HortScience 23: 779-781.

Gardner RG and Shoemaker PB (1999) 'Mountain Supreme' early blight resistant hybrid tomato and its parents, NC EBR-3 and NC EBR-4. HortScience 34: 745-746.

Hallauer AR and Miranda Filho JB (1988) Quantitative genetics in maize breeding. Iowa State University Press, Ames, 468p.

Holm AL, Rivera VV, Secor GA and Gudmestad NC (2003) Temporal sensitivity of Alternaria solani to foliar fungicides. American Journal of Potato Research 80: 33-40.

Horsfall JG and Barratt RQ (1945) An improved grading system for measuring plant diseases. Phytopathology 35: 655 .

Jones JB, Jones JP, Stall RE and Zitter TA (1991) Infectious antifungal. Plant Physiology 108: 17-27.

Kranz J (1988) Measuring plant disease. In Kranz J and Rotem J (eds.) Experimental techniques in plant disease epidemiology. Springer-Verlag, Heidelberg, p.35-50. 
JFJ Grigolli et al.

Lopes CA and Santos JRM (1994) Doenças do tomateiro. Embrapa/CNPH, Brasília, 67p.

Maffia LA, Martins MCP and Matsuoka K (1980) Doenças do tomateiro. Informe Agropecuário 6: 42-60.

Maiero M, Ng TJ and Barksdale TH (1989) Combining ability estimates for early blight resistance in tomato. Journal of the American Society for Horticultural Science 114: 118-121.

Maiero M, Ng TJ and Barksdale TH (1990) Genetic resistance to early blight in tomato breeding lines. HortScience 25: 344-346.

Martin FW and Hepperly P (1987) Sources of resistance to early blight, Alternaria solani, and transfer to tomato, Lycopersicon esculentum. Journal of Agriculture of the University of Puerto Rico 71: 85-95.

Morales EAV, Valois ACC and Nass LL (1997) Recursos genéticos vegetales. SPI, Brasília, 79p.

Nash AF and Gardner RG (1988) Tomato early blight resistance in a breeding line derived from Lycopersicon esculentum PI 126445. Plant Disease 72: 206-209.

Nutter FW and Litwiller D (1998) Programa severity pro 1.0 Iowa State University.

Patterson JM and Nokes SE (2000) Incorporation of chlorothalonil persistence on processing tomato into TOMCAST. Agricultural Systems 64: 171-187.

Paula RS and Oliveira WR (2003) Resistência de tomateiro (Lycopersicon esculentum) ao patógeno Alternaria solani. Pesquisa Agropecuária Tropical 33: 89-95.

Ribeiro AC, Guimarães PTG and AlvarezV VH (1999) Recomendações para o uso de corretivos e fertilizantes em Minas Gerais: 5a Aproximação. Editora UFV, Viçosa, 359p.
Rotem J (1994) The genus Alternaria: biology, epidemiology, and pathogenicity. APS Press, St Paul, 326p.

Schuelter AR, Marochio J, Souza CS, Philippsen CCO, Heck MC, Lannes SD, Schuster I, Finger FL and Souza IRP (2006) Genetic control of modified genomic region in a firm ripening tomato (Lycopersicon esculentum Mill.) mutant. Crop Breeding and Applied Biotechnology 6: 261-268.

Sherf AF and Macnab AA (1986) Tomato. In Sherf AF and Macnab AA (eds.) Vegetable diseases and their control. John Wiley \& Sons, New York, p. 599-696.

Silva DJH, Moura MC and Casali VWD (2001) Banco de germoplama de Hortaliças - UFV: histórico e conteúdo. Horticultura Brasileira 19: 108-114.

Tambarussi EV, Melotto-Passarin DM, Gonzalez SG, Brigati JB, Jesus FA, Barbosa AL, Dressano K and Carrer H (2009) In silico analysis of Simple Sequence Repeats from chloroplast genomes of Solanaceae species. Crop Breeding and Applied Biotechnology 9: 344-352.

Tófoli JG and Kurozawa C (1993) Avaliação da resistência de cultivares e híbridos de tomateiro à pinta preta (Alternaria solani). Summa Phytopathologica 19: 39-40.

Vale FXR, Zambolim L and Chaves GM (1992) Avaliação fitossanitária da cultura do tomateiro em regiões produtoras de Minas Gerais e Espírito Santo. Fitopatologia Brasileira 17: 211.

Vallois ACC, Salomão AN and Allem AC (1996) Glossário de recursos genéticos vegetais. $\mathrm{SPI}$, Brasília, 62p. 